Original Research Article

\title{
Anti-ulcer effect of rhizome of Curcuma longa Linn, by the method of pyloric ligation
}

\author{
Jayan Pariyani Savaringal*, Sanalkumar K. B.
}

Department of Pharmacology, Govt. Medical College, Thrissur, Kerala, India

Received: 16 November 2017 Accepted: 21 November 2017

\section{*Correspondence to:}

Dr. Jayan Pariyani Savaringal, Email: jayanpsr@gmail.com

Copyright: (C) the author(s), publisher and licensee Medip Academy. This is an openaccess article distributed under the terms of the Creative Commons Attribution NonCommercial License, which permits unrestricted noncommercial use, distribution, and reproduction in any medium, provided the original work is properly cited.

\begin{abstract}
Background: Substantial part of the world population has been known for a long time to suffer from peptic ulcer disease. In the present study, Curcuma longa, a plant belonging to the Zingiberaceae family was chosen for investigating its antiulcer properties.

Methods: The rhizomes of Curcuma longa were collected locally. The extract was prepared by soxhlet extraction with $50 \%$ ethanol. Albino rats of Wistar strain (120-200 grams) obtained from the animal house of medical college Thiruvananthapuram were used. Ranitidine was collected from Kerala Sate Drugs and Pharmaceutical LTD Alapuzha. Antiulcer study in rats were done using the method of pyloric ligation.

Results: Antiulcer study in rats using the method of pyloric ligation, extract of Curcuma longa in $1000 \mathrm{mg} / \mathrm{Kg}$ dose levels exhibited significant protection against shay ulceration. The results were comparable to that of standard drug Ranitidine.

Conclusions: The present study with extract of Curcuma longa revealed that it has significant anti-ulcer activity.
\end{abstract}

Keywords: Curcuma longa, Pyloric ligation, Ranitidine, Shay ulceration

\section{INTRODUCTION}

Peptic ulcer is a multifactorial disease. Factors like increased stress, impaired mucosal resistance, genetic factors, infection with $H$. pylori and anti-inflammatory drugs including NSAIDs damage gastric mucosa. In the present study, Curcuma longa, a plant belonging to the Zingiberaceae family was chosen for investigating its antiulcer property.

Curcuma longa has an important place in the Indian household. It is considered auspicious in all religious observations in Indian households. It is a normal constituent of condiments and curry powders. Curcuma longa, which have a prominent place in Indian system of medicine, have attracted the interests of scientists and were subjected to extensive research.
Constituents of Curcuma longa exert several protective effects on the gastrointestinal tract. A salt of curcumin, sodium curcuminate, was found to inhibit intestinal spasm, and p-tolymethylcarbinol, a turmeric component, was found capable of increasing gastrin, secretin, bicarbonate, and pancreatic enzyme secretion. ${ }^{1}$. Curcuma powder has been reported to increase gastric wall mucus, in a study conducted by Rafathullah S and coworkers. ${ }^{2}$ Curcuma powder has been reported to increase the mucin content of gastric juice in rabbits. It may thus be beneficial in protecting the gastric mucosa from irritants. ${ }^{3}$ By the method of receptor combination, effects of the active constituents in Curcuma longa on gastrin receptor were studied by Xiao X and coworkers. ${ }^{4}$ The results showed that Curcuma longa have antagonistic action on gastrin receptor. Mahady GB and coworkers found that methanol extract of Curcuma longa and curcumin inhibit growth of 
all strains of Helicobacter pylori in vitro, with minimum inhibitory concentration of $6.25-50 \mu \mathrm{g} / \mathrm{ml} .^{5}$

Curcumin was found to have anti-ulcer activity during the acute chronic phase of gastric ulcer comparable to omeparazole and promotes gastric ulcer prevention /healing by induction of angiogenesis in granular tissue of ulcers by a study conducted by Karoin Kamel Abdul Aziz. ${ }^{6}$

\section{METHODS}

\section{Plant material}

The rhizomes of Curcuma longa were collected locally and pharmacognostically identified before use. Its botanical identity was confirmed and certified by the Pharmacognosy unit, Ayurvedic Research Institute (A.R.I), Poojappura, Thiruvananthapuram. The rhizomes were washed with water, air-dried and cut into small pieces. The extract was prepared by soxhlet extraction with $50 \%$ ethanol. The percentage yield was 4.7.

\section{Animals}

Albino rats of Wistar strain (120-200gm) obtained from the animal house of medical college Thiruvananthapuram were used. They were fed a standard diet and maintained under standard laboratory conditions

\section{Drugs}

Ranitidine was collected from Kerala State Drugs and Pharmaceutical LTD Alappuzha.

\section{Antiulcer study in rats using the method of pyloric ligation ${ }^{7}$}

Albino rats weighing 150-200gm of both sexes were used for the study. They were randomized in to 5 groups, each group having 6 animals. They were starved for 48 hours having, access to drinking water ad libitum. During this time, they were housed in single cages with raised bottoms of wide wire mesh in order to avoid cannibalism and coprophagy. Aqueous preparation of extract of Curcuma longa and other compounds were given orally one hour prior to pyloric ligation in the following manner.

- Group I (Control): Distilled water (1 $\mathrm{ml} / 100 \mathrm{gm}$ body weight)

- Group II (Standard): Ranitidine in a dose of $50 \mathrm{mg} / \mathrm{Kg}$ body weight

- Group III (Test Group 1): Ethanolic extract of Curcuma longa in a dose of $250 \mathrm{mg} / \mathrm{Kg}$ body weight suspended in distilled water.

- Group IV (Test Group2): Ethanolic extract of Curcuma longa in a dose of $500 \mathrm{mg} / \mathrm{Kg}$ body weight suspended in distilled water.

- Group V(Test Group 3): Ethanolic extract of Curcuma longa in a dose of $1000 \mathrm{mg} / \mathrm{Kg}$ body weight suspended in distilled water.
Under light ether anaesthesia a midline abdominal incision was made. The pylorus of the rat stomach was ligated, care being expressed that neither damage to blood supply or traction on the pylorus occurs. Grasping the stomach with, instruments are carefully avoided to prevent development of ulcers at such points. With sutures closed the abdominal wall. Thereafter animals were maintained in cages without food or water and sacrificed at the end of 19 hours by an overdose of ether. The abdomen was opened, and a ligature is placed around the oesophagus close to the diaphragm. The stomach was removed, and contents are drained in a centrifuge tube. Along the greater curvature, stomach was opened and pinned on a cork plate. Stomach contents were centrifuged and subjected to analysis for free acidity and total acidity using the following formula. ${ }^{9}$

$$
\text { Free acidity }(\mathrm{mmol} / \mathrm{L})=\frac{\mathrm{ml} \text { of } \mathrm{NaOH}(0.10 \mathrm{~mol} / \mathrm{L}) \times 0.1 \times 1000}{\mathrm{ml} \text { of gastric specimen titrated }}
$$

A known volume of gastric residue is titrated with Sodium hydroxide $(\mathrm{NaOH}), 0.10 \mathrm{~mol} / \mathrm{L}$, using Toepfer's reagent (diethyl amino azo benzene in ethanol) added to gastric juice, until it becomes salmon coloured. If the gastric fluid contains food particle it should be centrifuged. By using $\mathrm{P}^{\mathrm{H}}$ meter or $\mathrm{P}^{\mathrm{H}}$ paper the approximate acidity of the sample can be measure. If the $\mathrm{P}^{\mathrm{H}}$ is above 3.5 no free acid is present. Such a specimen of gastric fluid should not be titrated for free acidity.

Total acidity in the gastric specimen is determined by titrating it with Sodium hydroxide $(\mathrm{NaOH}), 0.10 \mathrm{~mol} / \mathrm{L}$, using Phenol red as indicator added to gastric specimen. Gastric specimen is titrated to a $\mathrm{P}^{\mathrm{H}}$ of 7 for calculating total acidity using the same formula for free acidity.

$$
\text { Total acidity }(\mathrm{mmol} / \mathrm{L})=\frac{\mathrm{ml} \text { of } \mathrm{NaOH}(0.10 \mathrm{~mol} / \mathrm{L}) \times 0.1 \times 1000}{\mathrm{ml} \text { of gastric specimen titrated }}
$$

The volume of gastric fluid was expressed in $\mathrm{ml} / 100 \mathrm{gm}$ body weight. The total ulcer in each stomach is noted. Severity of each ulcer was recorded in the following manner. ${ }^{10}$

0-No ulcer; 1-Pinpoint ulcer, histological changes limited to superficial layers of mucosa, No congestion. 2-Ulcer size less than $1 \mathrm{~mm}$, congestion present. 3-Ulcer size 1$2 \mathrm{~mm}$, deeper involvement of mucosa, necrosis and congestion present. 4-Ulcer size more than $2 \mathrm{~mm}$ in size or perforated with complete destruction of mucosa.

Ulcer index was calculated using the following formula: ${ }^{11}$

$$
\mathrm{U}_{\mathrm{i}}=\mathrm{U}_{\mathrm{n}}+\mathrm{Us}+\mathrm{Up} \times 10^{-1}
$$

Ui $=$ Ulcer index. Un $=$ Average number of ulcers per animal, Us = Average of severity score, $\mathrm{Up}=$ Percentage of animals with ulcer

Specimens were collected in formalin filled bottles for histopathological study. 
Histopathological study: Specimens of stomach after pyloric-ligation were kept in $10 \%$ formalin solution for fixation of tissues. Paraffin sectioning of fixed tissues was done using standard protocol (microtomy) and tissues were stained with haematoxylin and eosin and examined under a light microscope.

\section{Statistical analysis}

Statistical analysis was done by one-way ANOVA (Analysis of variance) to compare the means in the experimental groups. Mean and standard deviation was found out. Duncans multiple range (DMR) test (Post Hoc analysis using DMR test) was done to find out the significance of various test results.

Table 1: Effect of test compounds given on pyloric ligation.

\begin{tabular}{|lllllll|}
$\begin{array}{l}\text { Group } \\
\text { (no- 6) }\end{array}$ & Drug & $\begin{array}{l}\text { Dose / kg } \\
\text { body weight }\end{array}$ & $\begin{array}{l}\text { Volume of gastric } \\
\text { juice ml/100gm } \\
\text { Mean } \pm \text { SE }\end{array}$ & $\begin{array}{l}\text { \% } \\
\text { animals } \\
\text { with ulcer }\end{array}$ & $\begin{array}{l}\text { No of gastric } \\
\text { ulcer } \\
\text { Mean } \pm \text { SE }\end{array}$ & $\begin{array}{l}\text { Ulcer } \\
\text { score } \\
\text { Mean } \pm \text { SE }\end{array}$ \\
\hline I & Vehicle & 50 & $4.40 \pm 0.22$ & 100 & $4.17 \pm 0.75$ & $1.69 \pm 0.18$ \\
\hline II & Ranitidine & $2.88 \pm 0.26$ & 50 & $0.5 \pm 0.55$ & $0.5 \pm 0.55$ \\
\hline III & Extract of Curcuma longa & 250 & $4.47 \pm 0.18$ & 100 & $3.83 \pm 0.75$ & $1.55 \pm 0.27$ \\
\hline IV & Extract of Curcuma longa & 500 & $4.36 \pm 0.16$ & 83.33 & $2.00 \pm 1.1$ & $1.03 \pm 0.54$ \\
\hline V & Extract of Curcuma longa & 1000 & $4.50 \pm 0.28$ & 50 & $0.50 \pm 0.55$ & $0.67 \pm 0.82$ \\
\hline
\end{tabular}

Table 2: Ulcer index, free acidity and total acidity.

\begin{tabular}{|llllll|}
\hline Group & & $\begin{array}{l}\text { Dose/kg } \\
\text { body weight }\end{array}$ & $\begin{array}{l}\text { Ulcer index } \\
\text { (UI) }\end{array}$ & $\begin{array}{l}\text { Acidity meq/l } \\
\text { Free acidity } \\
\text { mean } \pm \text { SE }\end{array}$ & $\begin{array}{l}\text { Total acidity } \\
\text { mean } \pm \text { SE }\end{array}$ \\
\hline I & Vehicle & & $15.86 \pm 0.18$ & $45.00 \pm 3.50$ & $83.317 \pm 2.96$ \\
\hline II & Ranitidine & 50 & $6.00 \pm 0.55$ & $00.000 \pm 0.00$ & $40.555 \pm 2.51$ \\
\hline III & Extract of Curcuma longa & 250 & $15.38 \pm 0.27$ & $43.333 \pm 2.98$ & $76.667 \pm 2.98$ \\
\hline IV & Extract of Curcuma longa & 500 & $11.36 \pm 0.54$ & $43.333 \pm 2.98$ & $77.220 \pm 3.90$ \\
\hline V & Extract of Curcuma longa & 1000 & $6.17 \pm 0.82$ & $45.000 \pm 3.50$ & $76.110 \pm 4.91$ \\
\hline
\end{tabular}

\section{RESULTS}

Extract of Curcuma longa exhibited significant protection against shay ulceration in dose levels of $1000 \mathrm{mg} / \mathrm{kg}$ body weight comparable to ranitidine. At $500 \mathrm{mg} / \mathrm{kg}$ doses there was significant ulcer protection but less comparing to that of ranitidine.

Table 3: Results of statistical ANOVA for ulcer index in pyloric ligation.

\begin{tabular}{|c|c|c|c|}
\hline Groups & Ulcer index mean & SD & F-value \\
\hline Control & 15.857 & 0.1745 & \multirow{5}{*}{$502.294^{x \times x}$} \\
\hline Standard & 6.000 & 0.5477 & \\
\hline Drug 250 & 15.382 & 0.2699 & \\
\hline Drug 500 & 11.357 & 0.5410 & \\
\hline Drug 1000 & 6.1667 & 0.8165 & \\
\hline
\end{tabular}

$\mathrm{N}=6 ;{ }^{\times} \mathrm{p}<0.05 ;{ }^{\mathrm{x}} \mathrm{p}<0.01 ;{ }^{\mathrm{x} \times} \mathrm{p}<0.001$

Extract in the dose of $250 \mathrm{mg} / \mathrm{kg}$ was not effective and can be comparable to control. Ulcer index was $15.38 \pm 27$, $11.36 \pm 0.54$, and $6.17 \pm 82$ in dose levels of $250 \mathrm{mg} / \mathrm{Kg}$, $500 \mathrm{mg} / \mathrm{Kg}$ and $1000 \mathrm{mg} / \mathrm{Kg}$ body weight respectively. Ulcer index was $6.00 \pm 0.55$ in the ranitidine treated group whereas $15.86 \pm 0.18$ in control group. There is a dose dependent decrease in the ulcer index in test drug administered group.

Table 4: Analysis of variance for gastric volume in pyloric ligation.

\begin{tabular}{|c|c|c|c|}
\hline Groups & $\begin{array}{l}\text { Gastric } \\
\text { volume-Mean }\end{array}$ & SD & F value \\
\hline Control & 4,400 & 0.2242 & \multirow{5}{*}{$56.628^{x \times x}$} \\
\hline Standard & 2.883 & 0.2579 & \\
\hline Drug 250 & 4.468 & 0.1751 & \\
\hline Drug 500 & 4.363 & 0.1550 & \\
\hline Drug 1000 & 4.497 & 0.2809 & \\
\hline
\end{tabular}

Table 5: Analysis of variance for total acidity in pyloric ligation.

\begin{tabular}{|c|c|c|c|}
\hline Groups & Total acidity mean & SD & F-value \\
\hline Control & 83.317 & 2.961 & \multirow{5}{*}{$139.452^{x \times x}$} \\
\hline Standard & 40.555 & 2.507 & \\
\hline Drug 250 & 76.667 & 2.983 & \\
\hline Drug 500 & 77.220 & 3.897 & \\
\hline Drug 1000 & 76.110 & 4.906 & \\
\hline
\end{tabular}

$\mathrm{N}=6 ;{ }^{\mathrm{x}} \mathrm{p}<0.05 ;{ }^{\mathrm{x}} \mathrm{p}<0.01 ;{ }^{\mathrm{x} \times \mathrm{x}} \mathrm{p}<0.001$ 
There was no significant difference in free acidity and total acidity in between control and Curcuma longa extract treated groups. Whereas there is significant reduction in total acidity and volume of gastric juice in the case of ranitidine treated group. There was no significant change in the total volume and $\mathrm{P}^{\mathrm{H}}$ of gastric fluids in the test drug given group and control group.

Table 6: Analysis of variance for free acidity in pyloric ligation.

\begin{tabular}{|c|c|c|c|}
\hline Groups & Free acidity mean & SD & F- value \\
\hline Control & 45.000 & 3.497 & \multirow{5}{*}{$277.463^{x \times x}$} \\
\hline Standard & 00.000 & 0.000 & \\
\hline Drug 250 & 43.333 & 2.983 & \\
\hline Drug 500 & 43.333 & 2.983 & \\
\hline Drug 1000 & 45.000 & 3.497 & \\
\hline
\end{tabular}

Table 7: DMR Test for ulcer index in pyloric ligation.

\begin{tabular}{|c|c|c|}
\hline \multirow{2}{*}{ Groups } & \multicolumn{2}{|c|}{ Subset of alpha $=0.05$} \\
\hline & 1 & 3 \\
\hline Standard & 6.0000 & \\
\hline Drug 1000 & 6.1667 & \\
\hline Drug 500 & & 11.3567 \\
\hline Drug 250 & & 15.3817 \\
\hline Control & & 15.8567 \\
\hline
\end{tabular}

Means for groups in homogeneous subset are displayed. Uses harmonic sample size $=6.000$.

Table 8: DMR Test for gastric volume in pyloric ligation.

\begin{tabular}{|c|c|}
\hline \multirow{2}{*}{ Groups } & Subset of alpha $=0.05$ \\
\hline & 12 \\
\hline Standard & 2.8833 \\
\hline Drug 1000 & 4.3633 \\
\hline Drug 500 & 4.4000 \\
\hline Drug 250 & 4.4067 \\
\hline Control & 4.4967 \\
\hline
\end{tabular}

Means for groups in homogeneous subset are displayed. Uses harmonic sample size $=6.000$.

Table 9: DMR Test for free acidity in pyloric ligation.

\begin{tabular}{|ll|}
\hline Groups & \multicolumn{2}{l|}{ Subset of alpha $=\mathbf{0 . 0 5}$} \\
\hline Standard & $\mathbf{1}$ \\
\hline Drug 1000 & 0.000 \\
\hline Drug 500 & \\
\hline Drug 250 & 43.333 \\
\hline Control & 43.333 \\
\hline
\end{tabular}

Means for groups in homogeneous subset are displayed. Uses harmonic sample size $=6.000$.

Histopathology showed marked congestion, superficial layer of fibrinoid debris and inflammatory infiltrate with neutrophilic predominance in the mucosa. The lamina propria of mucosa surrounding the gastric ulcer was infiltrated by plasma cells, lymphocytes and few neutrophils in the control group. There was inflammatory infiltrated in the sub mucosa also. Similar changes were seen in extract treated groups in doses of $250 \mathrm{mg} / \mathrm{kg}$ and $500 \mathrm{mg} / \mathrm{kg}$ body weight. Extract treated group in the dose of $1000 \mathrm{mg} / \mathrm{kg}$ and ranitidine treated group showed minimum inflammatory infiltrate with mild congestion. Gastric mucosal erosion was absent.

Table 10: DMR Test for total acidity in pyloric ligation.

\begin{tabular}{|c|c|}
\hline \multirow{2}{*}{ Groups } & Subset of alpha $=\mathbf{0 . 0 5}$ \\
\hline & 1 \\
\hline Standard & 40.555 \\
\hline Drug 1000 & 76.110 \\
\hline Drug 500 & 76.668 \\
\hline Drug 250 & 77.220 \\
\hline Control & 83.317 \\
\hline
\end{tabular}

\section{DISCUSSION}

Most simply a peptic ulcer can be defined as disruption of the mucosal integrity of stomach and/or duodenum leading to a local defect or excavation due to active inflammation. $98 \%$ of peptic ulcers are located either in the first portion of the duodenum or in the stomach in a ratio of $4: 1$. Peptic ulcer is one of most common disease in man. It is considered as one of major human sufferings today affecting nearly $5 \%$ of the global population. Ulceration of the stomach mainly develops in the antral region due to lesions in the gastric mucosa. Since in majority of cases it is aggravated due to pepsin and hydrochloric acid it is termed as peptic ulcer Natural course of ulcer disease is characterized by numerous episodes of spontaneous healing, frequent relapses, and occasional complications.

Table 11: Aggressive and defensive factors affecting gastric mucosal integrity.

\begin{tabular}{|ll|}
\hline Aggressive factors & Defensive factors \\
\hline Gastric acidity & Prostaglandins \\
\hline Pepsin & Bicarbonate \\
\hline Bile acids & Mucus \\
\hline Impairment of motility & Phospholipids \\
\hline Nicotine & Epidermal growth factors \\
\hline NSAIDS & Intact microcirculation \\
\hline Corticosteroids & Epithelial renewal \\
\hline H. pylori & Alkaline tide \\
\hline
\end{tabular}

Gastro duodenal mucosal injury results from an imbalance between the factors that damage the mucosa and those that protect it.

Pathogenic process of gastric ulceration may be even more heterogeneous than that of duodenal ulceration and there is little doubt that gastric ulcer is a multifactorial disease. 
Johnson classified gastric ulcers in to 3 groups; Type 1 are corpus ulcers, type 2 are gastric ulcers associated with duodenal ulcers and type 3 are peripyloric ulcers. Prepyloric ulcers are generally regarded to behave similarly to duodenal ulcers mainly because they are associated with normal to high acid secretion.

Curcuma longa has been used in traditional medicine for treating various diseases. The present study supports the traditional use of this plant against gastric problems.

A survey of the effects of clinically useful drugs on experimental ulcer suggests that the pylorus-ligated rat ulcer test is probably the best single ulcer model for prediction of clinical usefulness. ${ }^{12}$ Here antiulcer effect of alcoholic extract of Curcuma longa in shay ulceration in dose of $1000 \mathrm{mg} / \mathrm{kg}$ body weight showed significant ulcer protective action comparable to ranitidine even though extract did not possess effect on gastric acidity and gastric volume. In a study it was found that, basal and Penta gastrin-stimulated maximal acid output and parietal cell sensitivity (as measured by the ratio of small-dose to maximal-dose stimulated acid output) fell significantly, 3 days after the duodenal ulcer had been healed with sucralfate, which does not interfere with the physiological process of acid secretion where as in ulcers healed with ranitidine, there was no impressive fall. ${ }^{13}$ A significant fall was also not observed by the same group after healing with omeprazole or antacids. ${ }^{14}$ In another study it was found that patients who did not exhibit such a fall, particularly with respect to parietal cell sensitivity, had a high chance of subsequent relapse. ${ }^{15}$ Parietal cell hypersensitivity or up-regulation has been documented after cessation of treatment with $\mathrm{H}_{2}$-receptor antagonists. ${ }^{16}$ It may be the reason for the early relapse associated with treatment by $\mathrm{H}_{2}$-receptor antagonists comparing with treatment by drugs like colloidal bismuth, sucralfate and carbenoxolone sodium, which does not make many changes with the physiologic process of acid secretion. In the present study it is found that extract of Curcuma longa is not making much difference in gastric fluid volume and acidity. This gives an advantage for extract of Curcuma longa in reducing relapse rate of peptic ulcer, after long term treatment comparing to $\mathrm{H}_{2}$-receptor antagonists.

In a study conducted for pharmacological evaluation of compound UP5145-52, it was found that cytoprotection could play an important role in the anti-ulcer efficacy of the molecule. ${ }^{17}$ Various Physical and psychological stresses cause gastric ulcer in human and experimental animals. ${ }^{18,19}$ The mechanisms linking psychological factors to ulcer disease are unclear. Electric shocks delivered to monkeys have led to the formation of gastric ulcers. Increased circulating neurotransmitters and local cytotoxic mediators including thromboxanes and leukotrienes, which represent responses to stress and impaired mucosal defences, are documented in the case of peptic ulcer related to stressful situations. ${ }^{20}$ Singh RK and co-workers found that all extracts (petroleum ether, benzene, chloroform, acetone, and ethanolic) of Abies pindrow leaf showed ulcer-protective effect in a model of cold restraint stress because of their anti-stress effects. ${ }^{21}$ In a study conducted by $\mathrm{Yu} \mathrm{ZF}$ and co-workers, in mice it was found that the aqueous extracts of Curcuma longa when administered orally have significant antidepressant activity and at the dose of $560 \mathrm{mg} / \mathrm{kg}$ was more potent than that of reference antidepressant Fluoxetine. ${ }^{22}$ This action of extracts of Curcuma longa may be useful in the long term management of stress induced peptic ulcer.

In the present study, extract of Curcuma longa showed a significant protection against the experimental ulcers induced by pyloric ligation. The extract showed no change in gastric juice volume or acid concentration. Extract of Curcuma longa on various models suggests its diverse role in ulcer protection, which may include its reported effect on wound healing and as an anti-oxidant. ${ }^{23}$ The effect of gastric mucosal cells of patients with gastric ulcer have been considered immature and incapable of producing adequate mucin, which histologically appears to be decreased in the mucosa of such patients. ${ }^{24}$ A prevalence of non-secreting surface mucous cells has been observed by scanning electron microscopy in patients with gastric ulcer. $^{25}$ Also suggested is that gastric mucous glycoproteins are abnormal in gastric ulcer, which results in week mucous gel structure. ${ }^{26}$ Use of natural drugs in gastric ulcers is well documented. ${ }^{27-29}$ Most of these drugs augment the mucosal defensive factors, which are thought to be important for protection of gastric mucosa. ${ }^{30}$ Peptic ulcers are reported to be due to an imbalance between offensive acid-pepsin secretion and defensive mucosal factors like mucin secretion and cell shedding. ${ }^{31}$ Constituents of Curcuma longa exert several protective effects on the gastrointestinal tract. A salt of curcumin, sodium curcuminate, was found to inhibit intestinal spasm, and p-tolymethylcarbinol, a turmeric component, was found capable of increasing bicarbonate, and pancreatic enzyme secretion. ${ }^{1}$ Curcuma powder has been reported to increase gastric wall mucus, in a study conducted by Rafathullah S. and coworkers. ${ }^{2}$ It may thus be beneficial in protecting the gastric mucosa from irritants. ${ }^{3}$ In another study oral administration of curcumin in rats caused, a significant reversal of lipid peroxidation, in brain lipids, and produced enhancement of glutathione; a nonenzymatic anti-ioxidant. ${ }^{32}$ In case of peptic ulcer inflammatory mediators play an important role along with involvement of free radical injury and lipid peroxidation. By the method of receptor combination, an effect of the active constituents in rhizomes of Curcuma longa on gastrin receptor was studied by Xiao X and coworkers. ${ }^{4}$ The results showed that Rhizome of Curcuma longa act as antagonist of gastrin receptor. The anti-ulcer effects of turmeric and curcumin may be due in part to direct antioxidant and free radical scavenging effect. But it also enhances the body's natural antioxidant system, increasing glutathione levels that also may be contributing to its antiulcer effect. ${ }^{33}$

Mahady GB and co-workers found that methanol extract of Curcuma longa and curcumin inhibit growth of all 
strains of Helicobacter pylori in vitro, with minimum inhibitory concentration of $6.25-50 \mu \mathrm{g} / \mathrm{ml} .^{5} H$. pylori is a gram-negative spiral bacterium found in association with gastric epithelium. It is considered, as a major cause of chronic type B gastritis in the human and type B gastritis is closely associated with peptic ulcer, particularly gastric ulcer. The infection is recognized as a risk factor for gastric malignancies such as adenocarcinoma and mucosa associated lymphoid tissue (MALT) lymphoma. ${ }^{34}$ Toda. S and co-workers found that water and fat-soluble extracts of turmeric and its curcumin component exhibit strong antioxidant property comparable to vitamins $\mathrm{E}$ and $\mathrm{C} .{ }^{35}$ Thus the potent anti-inflammatory, anti-H. pylori, and antioxidant effect of Curcuma longa extract and curcumin may help in the long term anti-ulcer therapy complicated by concomitant $H$. pylori infection. The anti-cancer properties may also helpful in the long-term treatment of peptic ulcer complicated by $H$. pylori infection since infection with $H$. pylori is considered as a risk factor for gastric malignancies. ${ }^{34}$

Curcumin was shown to inhibit neutrophil aggregation associated with inflammation. ${ }^{36}$ Srihari and co-workers found that the extract of Curcuma longa blocked the stimulant effect of histamine in guinea pig ileum. ${ }^{37}$ Muscle spasm induced by electrical vagal stimulation has been shown experimentally to produce acute gastric ulcers. ${ }^{38}$ In an article review done by Ishita Chattopadhyay and coworkers, shows many beneficial effects of curcumin on the stomach. Curcumin has been shown to protect the stomach from ulcerogenic effects of phenylbutazone and 5hydroxytryptmine in pigs. ${ }^{39}$

A salt of curcumin, sodium curcuminate, was found to inhibit intestinal spasm. ${ }^{1}$ Consumption of turmeric for 4 and 8 weeks shows beneficial effect in patients with peptic ulcer and shows significant anti $H$. pylori effect. ${ }^{40}$ These actions may contribute if extract of Curcuma longa is used in the chronic management of peptic ulcer specially to prevent relapse. Further in vitro and in vivo studies are needed to confirm these findings.

\section{CONCLUSION}

The study revealed that extract of rhizome of Curcuma longa has significant anti-ulcer activity. Further studies have to be conducted to explain precisely the mechanism of action of this drug.

\section{Funding: No funding sources}

Conflict of interest: None declared

Ethical approval: The study was approved by the Institutional Ethics Committee

\section{REFERENCES}

1. Ammon HPT, Wahl MA. Pharmacology of Curcuma longa. Planta Medica. 1991;57:1-7.

2. Rafathullah S, Tariq M, Al-Yahya MA, Mossa JS, Ageel AM. Evaluation of Curcuma longa for gastric and duodenal ant-ulcer activity in rats. J Ethanopharmacol. 1990;29(1):25-34.

3. Mukherjee B, Zaidi SH, Singh GB. J of Sci Industr Res. 1961;20:25-8.

4. Xiao X, Zhao Y, Yuan H, Xia W, Zhao J, Wang X. Study on the effect of Rhizoma Curcuma longa on gastrin receptor. Zhong Yao Cai. 2002;25(3):184-5.

5. Mahady GB, Pendland SL, Yun G, Li ZZ. Inhibitory action of turmeric and curcumin on the growth of H.pylori, a group - Ì carcinogen. Anticancer Res. 2002;22(6):4179-81.

6. Abdul-Aziz KK. Comparative evaluation of the antiulcer activity of curcumin and omeprazole during the acute phase of gastric ulcer. Food Nut Sci. 2011;2:628-40.

7. Shay H, Komarov SA, Fels SS, Meranzie D, Gruenstein M, Siplet H. Gastroenterology. 1945; 5:43.

8. Badilla B, Miranda T, Mora G, Vargus K. The gastrointestinal activity of an aqueous extract of the dry wood of Quassia amara. Revi Biol Tropical. 1998; 46(2):203-10.

9. Burtis CA, Ashwood ER. Tietz Text Book of Clinical chemistry. $3^{\text {rd }}$ Ed. London. W. B. Saunders Company. 1999;1288-9.

10. Sairam K, Rao CV, Goel RK. Effect of Centella asiatica Linn. on physical and chemical factors induced gastric ulceration and secretion in rats. Indian J Exp Bio. 2001;39(2):137-42.

11. Vogel GH, Vogel WH. Drug Discovery and Evaluation: pharmacological assays. $1^{\text {st }}$ Ed. Berlin. Springer; 1997:487.

12. Brodie DA. Experimental gastric ulcers. Gastroenterology. 1968;55:125-34.

13. Marks IN, Young GO, Tigler-Wybrandi NA, Bridger S, Newton KA. Acid-secretory response and parietal cell sensitivity in patients with duodenal ulcer before and after treatment with sucralfate or ranitidine. The American journal of medicine. 1989;86(6):145-7.

14. Johnston DA, Marks IN, Young GO. Acid secretory responses and parietal cell sensitivity following duodenal ulcer healing with omeprazole, sucralfate, and Maalox. Am J Med. 1991;91:915-45.

15. Marks IN, Jonston DA, Young GO. Acid secretory changes and early relapse following duodenal ulcer healing. Am J Med. 1991;91:955-1015.

16. Jones DB, Howden CW, Burget DW. Alteration of $\mathrm{H}_{2}$ receptor sensitivity in duodenal ulcer patients after maintenance treatment with $\mathrm{H}_{2}$ receptor antagonists. Gut. 1988;29:890-3.

17. Dedieu-Chaufour CA, Hertz F, Caussade F, Cloarec A. Pharmacological profile of UP 5145-52, an original antiulcer and antisecretory agent. $\mathrm{J}$ of Pha and Exp The. 1991;259(1):190-7.

18. Miller TA. Mechanism of stress related mucosal damage. Am j Med. 1987;83:14.

19. Senay CE, Levine RJ. Synergism between cold and restraint for rapid production of stress ulcer in rats. Proc Soc Experimentation Biol Med. 1967;124:1221. 
20. Haubrich WS, Schaffner F, Berk JE, Bockus HL. Bockus gastroenterology. $7^{\text {th }}$ Ed. WB Saunders Co. 1995;714-732.

21. Singh RK, Nath G, Goel RK, Bhattacharya SK. Pharmacological actions of Abies pindrow Royale leaf. Indian J Exp Biol. 1998;36:187-91.

22. Yu ZF, Kong LD, Chen Y. Antidepressant activity of aqueous extracts of Curcuma longa in mice. J Ethnopharmacol. 2002;83(1-2):161-5.

23. Gujral ML, Chowdhury NK, Saxena PN. Wound healing property of curcuma powder Indian Med Assoc. 1953;22:273.

24. Domschke W, Domschke S, Hagel J. Gastric epithelial cell turn over mucous production and healing of gastric ulcers with carbenoxolone. Gut. 1977;18:81720.

25. Bonvicin F, Maltarello MC, Versura P. Correlative scanning electron microscopy in the study of human gastric mucosa. Scanning Electron Microsc. 1986;2:687-702.

26. Younan F, Pearson J, Allen A. Changes in the structure of the mucous gel on the mucosal surface of the stomach in association with peptic ulcer diseases. Gastroenterology. 1982;82:827-31.

27. Goel RK, Sairam K. Anti ulcer drugs from indigenous sources with emphasis on Musa sapientum, Tamrabhasma, Asparagus racemosus, and Zingiber officinale. Indian J Pharmacol. 2002;34:100-10.

28. Hiruma-Lima CA, Gracioso JD, Toma W, de Paula AC, De Almeida AB, Brasil DD, et al. Evaluation of the gastroprotective activity of cordatin, a diterpene isolated from Aparisthmium cordatum (Euphorbiaceae). Biol Pharm Bull. 2000;23(12):14659.

29. Antonio MA, Souza Brito AR. Oral anti-inflammatory and anti-ulcerogenic activities of a hydroalcoholic extract and partitioned fractions of Turnera ulmifolia (Turneraceae). J Ethnopharmacol. 1998;61(3):215-28.

30. Goel RK, Gupta S, Shankar R, Sanyal AK. Antiulcerogenic effect of Musa sapientum Var. paradisiaca
(Banana powder) and its effects on mucosal resistance. J Ethnopharmacol. 1996;18:33.

31. Goel RK, Bhattacharya SK. Gastroduodenal mucosal defence and mucosal protective agents. Indian J Exp Bio. 1991;29:701.

32. Mukherjee B, Zaidi SH, Singh GB. Journal of Sci Industr Res. 1961;20:25-8.

33. Pizorrno JE, Murray MT. Textbook of natural medicine, $2^{\text {nd }}$ Ed. London: Churchill Livingstone; 1999;689-693.

34. Ananthanarayanan R, Jayarampaniker CK. Textbook of Microbiology. $6^{\text {th }}$ Ed. Orient Longman Pvt Ltd; 2000:376-377.

35. Toda S, Miyase $\mathrm{T}$, Arich $\mathrm{H}$. Natural antioxidants: antioxidative compounds isolated from rhizome of Curcuma longa Linn. Chem Pharmacol Bull. 1985;33:1725-8.

36. Srivastava R. Inhibition of neutrophil response by curcumin. Agents Actions. 1989;28:298-303.

37. Srihari T, Basu N, Siddiqui HH. Action of extract of Curcuma longa on the stimulant effect produced on guinea pig ileum by histamine, serotonine and nicotine. Indian J Med Res. 1982;75:574-8.

38. Qvist G, Dormandy J, Brown C. The experimental production of gastric ulcers by induced muscle spasam. Br J Surg. 1974;61:259-63.

39. Chattopadhyay I, Biswas K, Bandyopadhyay U. Turmeric and curcumin: Biological actions and medicinal applications. current science-Bangalore. 2004;87(1):44-53.

40. Ajamal A. Effect of turmeric in peptic ulcer and Helicobacter pylori. Plant Sciences Research. 2011;3(3):25-8.

Cite this article as: Savaringal JP, Sanalkumar KB. Anti-ulcer effect of rhizome of Curcuma longa Linn, by the method of pyloric ligation. Int $\mathrm{J}$ Basic Clin Pharmacol 2018;7:20-6. 